\title{
Herbal drugs and drug interactions
}

\author{
Gül Dülger1
}

\begin{abstract}
Herbal drugs are defined as any form of a plant or plant product that contains a single herb or combinations of herbs that are believed to have complementary effects. Although they are considered to be safe, because they are natural, they may have various adverse effects, and may interact with other herbal products or conventional drugs. These interactions are especially important for drugs with narrow therapeutic indices.
\end{abstract}

In the present study, pharmacokinetic and pharmacodynamic interactions of some most commanly used herbals (St John's wort, ginkgo biloba, ginseng, ginger, garlic, echinacea, ephedra and valerian) with the conventional drugs were reviewed. Pharmacokinetic interactions involve mainly induction or inhibition of the cytochrome P450 isozymes and p-glycoproteins by the herbal medicine, thus changing the absorption and/or elimination rate and consequently the efficacy of the concommitantly used drugs. St John's wort, a well known enzyme inducer, decreases the efficacy of most of the other drugs that are known to be the substrates of these enzymes.

Pharmacodynamic interactions may be due to additive or synergistic effects which results in enhanced effect or toxicity, or herbal medicines with antagonistic properties reduce drug efficacy and result in therapeutic failure. For exampla, St John's wort may have synergistic effects with other antidepressant drugs used by the patient, resulting in increased CNS effects.

Herbals like ginseng, ginkgo, garlic, ginger were reported to increase bleeding time, thus potentiating the effect of anticoagulant and antithrombotic agents. In conclusion, patients should be warned against the interaction between the herbal products and conventional medicines.

KEY WORDS: StJohn's wort, garlic, ginkgo, ginger, ginseng,

\section{INTRODUCTION}

Herbs (herbal drugs) are generally defined as any form of a plant or plant product, including leaves, flowers, stems, roots and seeds, and they may contain a single herb or combinations of several different herbs that are believed to have complementary effects (1). They are among the natural products which are also classified as dietary supplements, nutraceuticals or complementary and alternative medicines (CAM), and may also include minerals and animal products such as enzymes. According to a report published in the Journal of American Dietetic Association in 2000 (2), there are over 29,000 different dietary supplements available in the USA and an average of 1000 new products are added yearly. Sales of herbal products in Europe and USA combined, is reported to exceed $\$ 30$ billion (or higher according to different sources) annually (3-4). It is also stated that the wide spread promotion of complementary and alternative medicine (CAM) products in the popular media and the unsubstantiated health care claims seem to increase their demand, although there are no sufficient scientific evidence for their safety and efficacy $(1,3)$. This is also true for Turkey.

Herbs or herbal products have been used since the dawn of the humanity to treat illness and improve health, and according to The World Health Organization (WHO) an estimated 80 percent of the world's population presently uses herbal medicines for some aspect of primary health care. They are also commanly used by patients with certain chronic medical conditions including breast cancer, human immunodeficiency virus (HIV), asthma and rheumatological disorders (57). Main reason for their preference over the

\author{
AFFILIATIONS \\ ${ }^{1}$ Marmara Universitesi \\ Eczacılık, İstanbul, Türkiye

\section{CORRESPONDENCE} \\ Gül Dülger \\ E-mail: \\ gdulger@marmara.edu.tr \\ Received: \\ 23.11.2011 \\ Revision: \\ 13.12.2011 \\ Accepted: \\ 13.12.2011
}


pharmaceutical drugs is that they are available without prescription and they are commanly assumed to be safe. Comparison of a National Health Survey made in 2002 in the United States with that made in 1997 revealed that there was a $50 \%$ increase in the use of herbal supplements, which meant that in the United States 38 million adults (20\% of the population) were using these products and also that the use of herbal supplements in the USA is growing steadily by approximately $20 \%$ per year $(5,6,8-10)$. Other surveys reported even higher estimates of use, reaching 61 to $71 \%(1,11)$. We could not find a similar survey made in Turkey. Besides, in Turkey and in many other cuntries (especially in developing countries), it is common practice to use folk medicines or products prepared unofficially by people specializd in the field (called "aktar"; ie "herb and spice seller" in Turkey); some people even prepare their own remedies from raw material they buy from the market. Since they do not consider these products as drugs, they do not even mention using them, and it would be impossible to track down all of these uses. Unfortunately, in spite of this widespread use of herbal medicines, it is reported that relatively few physicians inquire about their use, and up to $70 \%$ of patients do not reveal their use of herbal medicines to their physicians and pharmacists $(3,7,9-12)$.

According to a study that was carried out in the USA, a total of 101 of 657 patients $(15.4 \%)$ reported using herb-dietary supplements (HDS), including echinacea (21.8\%), ginkgo biloba $(13.9 \%)$, garlic $(7.9 \%)$, St. John's wort (SJW, 6.9\%), ginseng $(6.9 \%)$, evening primrose oil (5\%), saw palmetto (4\%) and also some nonherbal dietary supplements including glucosamine (13.9\%), omega-3 fatty acids (13\%), cranberry (4\%), chondroitin $(5 \%)$, and coenzyme Q10 (5\%). Although they found no increased rate of adverse drug events (ADEs) among HDS users compared to nonusers, 14 percent of users had potentially dangerous interactions with their prescription drugs (5).

Many of the herbal products or supplements are unlicensed and manufacturers are not required to demonstrate efficacy, safety or quality $(3,5,10,12,13)$. Thus, although they are used widely, there is still little evidence to support the efficacy of the majority of these products (1). Besides, lack of regulations of quality control and product standardization makes it difficult to establish safe doses of herbal products; active components may vary 200-fold between manufacturer and batches $(12,13)$. According to the literature, significant evidence for efficacy was found only for garlic, ginger, ginkgo biloba, saw palmetto, SJW, echinacea, ephedra and valeriane, and in the present review we will mainly concentrate on the interactions with these herbal products.

Although the herbal products are often promoted as safe, because they are natural, they are not free of adverse effects. Many of them have serious side effects and these may be due to the direct toxic effects of the herb, allergic reactions, effect of contaminants as well as interactions with other herbal products or conventional drugs (12-16). Side effects may also be due to the contaminants in these products; high levels of heavy metals including mercury, lead and arsenic or undeclared pharmaceuticals, purposefully and illegally added to the herb to produce a desired effect, can be cited.

The global increase in the popularity of alternative medicines has raised renewed concerns regarding the increase in herbal drug adverse effects as well as the herb-drug interactions. The interaction between drugs and herbal medicines is a safety concern and these interactions are especially important for drugs with narrow therapeutic indices (3,5,11-14,17-23).

A survey made in 2007 demonstrated that $15 \%$ of the patients receiving conventional pharmacotherapy also take herbal products. Among these, potential herb-drug interactions were observed in $40 \%$ of the patients, but it is often difficult to establish the causative agent of a herb-drug interaction, especially if it occurs in patients receving multiple drug therapies. This is a substential public health problem since many patients who are known to be using one or more prescription drugs are also taking supplement preparations, and unfortunately only about one third of these patients were reported to tell their physician about their use of these products $(1,3,5,7,9,17)$.

\section{MATERIAL AND METHODS}

Pubmed International was searched for articles published about herbal drug interactions between the years 1997-2011. The search terms were herbal drug interactions, alternative medicine, nutriceuticals and names of the selected medicinal plants. Recent reviews dealing with herb-drug interactions were also searched for relevant information. Additional publications were identified by checking all reference lists. Since it would have been impossible to include all herbal drug interactions, only some most commanly used herbal medication were chosen and Chinese herbal medicines were ommited altogether. Some interesting case reports about interactions of individual products were also included.

\section{RESULTS}

Interaction of herbal products with other drugs will be the main topic of this review paper. Majority of suspected herbdrug interactions are identified through case reporting. All of the interactions with herbal products and conventional drugs are not known and even if it were, it would not have been possible to give them all in the context of a review paper. Thus, in the present review, only interactions between some commanly used herbal products and conventional drugs will be considered.

There can be pharmacokinetic or pharmacodynamic interactions between herbal medicines and conventional drugs, and if the pharmacokinetics and/or the pharmacodynamics of the drug is altered due to this interaction, potentially severe and may be life-threatening adverse reactions may ocur $(1,4,5,12$, 18,21-25). Pharmacokinetic interactions involve mainly induction or inhibition of the cytochrome $\mathrm{P} 450$ isozymes and p-glycoproteins, resulting in alterations in the absorption, distribution, metabolism or excretion of drugs $(4,14,18-21,24,25)$. Pharmacokinetic interactions generally result in a change in plasma drug levels of the prescription drug.

Pharmacodynamic interactions between drugs and herbal medicines may be due to an aditive or synergistic effect which will result in enhanced effect or toxicity, or herbal medicines may have antagonistic properties which are likely to reduce drug efficacy and result in therapeutic failure. The synergistic or antagonistic interaction between herbals and drugs often result from the competitive or complementary effect of the drug and the co-administered herbal constituent at the same drug target. These interactions may result in increased risks of 
central nervous system-related effects, hepatotoxicity or bleeding, among others $(11,14-17,21,24,25)$.

Many of the drugs that were reported to interact with herbs are substrates of cytochrome (CYP) P450 enzymes, in particular CYP3A4 and CYP2C9, and these enzymes are subject to induction or inhibition by some of the regularly used herbal medicines. Accordingly, some of the herbal-drug interactions have been demonstrated to be mediated by CYP modulation, resulting in altered drug clearence and effect. On the other hand, expression of some of the CYP enzymes, including CYP3A4 is closely regulated by the nuclear factor pregnane $\mathrm{X}$ receptor (PXR), a nuclear receptor protein that plays a critical role in the regulation of human cytochrome P450 3A4 (CYP3A4) and transport protein genes $(4,18,19,22,24,26,27)$. Some of the drugs including cyclosporine, digoxine, simvastatin, imatinip, indinavir, saquinavir, among others, that interact with herbals are substrates for P-glycoprotein, and most of them are also substrates for CYP3A4, that is, they are dual substrates for both CYP3A4 and P-glycoprotein (P-gp). Like CYP3A4, P-gp can be induced or inhibited by drugs or herbals, and is also regulated by PXR. Thus, if a drug is a substrate for both CYPs and P-gp, there is a higher probability that it will interact with herbal products (18-20,22-24). In fact, since herbal medicines are usually administered orally and may attain high concentrations in the gut lumen and the liver, they may significantly modulate the bioavailability of some orally administered drugs. There are many factors related to the patient, herb and the co-administered drug that may influence the clinical importance of drug interactions with herbs. For example, pharmacokinetic drug-herb interactions have more serious results with drugs with a narrow therapeutic range, such as warfarine or digoxin, since a small change in their plasma concentrations can lead to significant alterations in their therapeutic effect and/or toxicity.

In most cases the extent of drug interactions with herbs varies markedly among individuals, depending on inter-individual differences in drug metabolizing enzymes and transport proteins, co-medication with other drugs, age, among many other factors $(18,24,26,27)$.

Drugs that are identified to interact with herbals include anticoagulants and antithrombotic agents, cardiovascular drugs, immunusuppressants, sedatives and antidepressants, statins, anticancer drugs and anti-HIV agents. Most of the drugs that are known to interact with herbals are administered orally in long term treatments and many of them are substrates of cytochrome P450s (CYPs) and/or P-glycoprotein (P-gp). Herbal medicines that are reported to interact with drugs include garlic (Allium sativum), ginger (Zingiber officinale), ginkgo (Ginkgo biloba), ginseng (Panax ginseng), St. John's wort, echinasea, valerian and aphedra $(1,3,4,10,13,19-28)$ and these will be discussed in the present paper.

\section{Garlic (Allium sativum)}

Garlic is used medicinally mainly to treat hypercholesterolaemia and for prevention of atherosclerosis. It was demonstrated to have the potential to modify the risk of development of atherosclerosis by reducing blood pressure and thrombus formation as well as by lowering lipid and cholesterol levels $(9,10,12,14)$. It may also have vasodilator effects, thus is used by hypertensive subjects. Its active components are believed to be alliin/allicin and its degredation products and sulphurcontaining essential oils. Dosage forms of garlic are standardized for alliin content as well as garlic oil (25). Garlic may have pharmacokinetic or pharmacodynamic interactions with concomittanly used other drugs.

In a recent study in rats, it has been demonstrated that combined use of fresh garlic homogenate with captopril had synergistic effects in lowering the blood pressure, and also that captopril increased the antihyperlipidemic activity of garlic (2931). In another study in rats, garlic was observed to increase the bioavailability and decrease the clearance and elimination rate of hydrochlothiazide when administered orally; writers concluded that addition of garlic in moderate doses might result in beneficial effects during treatment of hypertension in patients with myocardial stress $(29,32)$.

Active constituents of garlic, especially alliin/allicin were demonstrated to have antioxidant properties and to inhibit the production and/or release of mediators such as platelet activating factor (PAF), adenosine, prostaglandins and thromboxane. It is believed that its inhibitory effect on the production and/or release of one or more of these mediators may result in a decrease in platelet function (25). In fact, garlic inhibits platelet aggregation in a dose dependent fashion; this effect seems to be irreversible and may potentiate the effect of other platelet inhibitors such as prostacyclin, forskolin, indomethacine and dipyridamole, or warfarin. There are case reports suggesting that garlic may influence platelet function and blood coagulation, thus leading to risk of bleeding $(3,11,33)$. Garlic has been demonstrated to increase the clotting time and international normalized ratio (INR) of warfarin (28). In an elderly male, spontaneous epidural haematoma was reported after ingestion of garlic (25). Patients consuming 600-900 mg garlic every day were reported to have a higher incidence of prolonged bleeding time than those who did not ingest garlic everyday (10). This inhibition of platelet function should be considered, and warrant patients to discontinue use of garlic at least 7 days prior to surgery, especially if postoperative bleeding is a concern or if the patients are given other antiplatelet drugs.

There are some reports implying that garlic oil may selectively inhibit CYP2E1, decreasing chloroxazone metabolism; however, this was not supported by further studies (13). In a recent study, it was demonstrated that in women with advanced breast cancer, coadministration of garlic supplement reduced the clearance of docetaxol by 23-35\%, although the difference did not achieve statistical significance (34). There are also other reports on pharmacokinetic interactions between garlic and other drugs. For example, Hajda et al. (2010) have demonstrated that ingestion of garlic for 21 days increased the expression of duodenal P-gp thus decreasing saquinavir bioavailability significantly (35) and this was supported in a recent in vitro study carried out in Caco-2 cell monolayers and rat intestine (36,37). Another trial has demonstrated that ritonavir could inhibit the metabolism of the active ingredients of garlic and increase its gastrointestinal toxicity. In summary, available data on drug interactions with garlic at the biotransformation or P-gp level are not sufficient to come to a definite conclusion, but people should be cautioned against a possible interaction between long term garlic use and CYP2E1 and P-gp substrates, or with antiretroviral drugs such as ritonavir and saquinavir $(9,13)$. 


\section{St. John's Wort (SJW) (Hypericum perforatum)}

St. John's Wort is a very popular antianxiety and antidepressant product. It has also been reported to block metastases and act against inflammation and lung fibrosis. Although SJW has a good safety profile, it can undergo both pharmacokinetic and pharmacodynamic interactions with many other drugs $(1,3,9)$.

It is known to be a strong inducer of hepatic and intestinal CYP450 enzymes as well as p-glycoproteins in the intestine through activation of pregnane $X$ receptor (PXR) (4,18-21,24$28,38-51)$. Hyperforin, its most active compound, has also been reported to be a potent activator of pregnane $X$ receptor (PXR) $(4,17-19,40-44,48,51,52)$. Due to this property, pharmacokinetic interactions may be observed when SJW is administered concommitently with drugs which are substrates of CYP enzymes and/or P-glycoproteins. Accordingly, the herbal medicines containing hypericum extract can significantly affect the absorption and/or elimination kinetics of many concomittently administered drugs, lowering their plasma concentrations and consequently their efficacy $(13,26-28,43,44,48,52)$. SJW has been demonstrated to induce CYP3A4, CYP2C9, CYP2E1, and CYP2C19, and interaction with probes of these enzymes were also confirmed by clinical trials. These findings predict that SJW will interact with all prescription drugs that are metabolized by these CYP enzymes, especially by CYP3A4 $(9,26,50,52-$ 55). A detailed information on the interaction of SJW with conventional drugs can be found in review articles by Zhou et al. (2004) (55) and Borrelli \&Izzo (2009) (52). Drugs whose bioavailability and/or rate of elimination is affected by SJW can be listed as antiepileptics (mephenytoin), benzodiazepines alprazolam, midazolam, and quazolam, or antidepressant amitriptyline $(4,7,12,41,56)$, oral contraceptives, hypoglyceamic drugs (gliclazide), anticoagulant drugs (warfarin, phenprocoumon) (57), drugs used in cardiovascular diseases (digoxin) (41), antiarrhythmic ivabradine, calcium channel antagonists nifedipine and verapamil, as well as antihyperlipidemic drugs simvastatin, pravastatin, and atorvastatin (54), the immunosuppressants cyclosporine (58) and tacrolimus, fexofenadine (59) and the anticancer drugs irinotecan, imatinib and docetaxel $(4,38,39,48,55,60,61)$. These are all substrates for CYP3A4 and/or P-glycoproteins. Since most of the drugs are administered orally, the interplay of both intestinal P-gp and CYP3A4 has a strong effect on the bioavailability of most of the orally administered drugs including cyclosporine, amitriptyline, digoxin, talinolol, warfarin, statins, HIV protease inhibitors and verapamil.

Some typical interactions of clinical relevance are worth mentioning. It was demonstrated that concommitant use of SJW at a daily dose of $300 \mathrm{mg} 3$ times a day significantly increased the oral clearence of nor-ethindrone and decreased the half-life of ethinyl estradiol. Breakthrough bleeding was observed in 7 of 12 women consuming SJW, compared to 2 of 12 women in the control group (53). However, in another study on 16 healthy female volunteers, concurrent ingestion of $500 \mathrm{mg}$ Hypericum extract for 3 months did not change the plasma concentrations of ethinylestradiol or desogestrel signifcantly. Still, it would be wise to warn the women who are consuming SJW that oral contraceptives may not afford sufficient protection and that unexpected pregnancies were reported in some women who consumed SJW while taking oral contraceptives (62).
It should be remembered that the interactions between SJW and anticancer drugs, anti-HIV drugs and immunosuppressants may have serious clinical consequences (52). A clinical study in cancer patients reported that treatment with SJW at $900 \mathrm{mg}$ / day orally for 18 days decreased the plasma levels of the active metabolite of irinotecan, SN-38, by $42 \%$. In healthy subjects, treatment for 2 weeks significantly decreased the systemic exposure of imatinib by $32 \%$ (34). Docetaxel metabolism was also demonstrated to be significantly induced in isolated donor hepatocytes by exposure to hyperforine (61). Many cancer patients are prone to use herbal medicines. Thus, potential interactions of herbal medicines with anticancer agents have become a safety concern in cancer chemotherapy. Further studies are warranted to investigate the efficacy and safety profiles of herbal medicines commonly used by cancer patients (60). This inducing effect of SJW on CYP enzymes or pglycoproteins is observed after long-term treatment, that is, at least in two weeks. The in vivo CYP3A4 activity is reported to return to basal levels progressively, in about 1 week after the cessation of SJW (63).

Enzyme inducing effect of SJW is well known, however there are some in vitro studies demonstrating the inhibitory effect of hyperforin on CYP enzymes. Hellum et al (2009) reported that among the herbal drugs they studied, SJW was the most potent CYP-modulating herb, showing a dose-dependent induction/inhibition of both CYP2C19 and CYP2E1, with induction at low dosages and inhibition at higher (64).

Hyperforin is the most active constituent of SJW, however, it has been demonstrated in many studies that there is great variability in the content of hyperforin among the commercial preparations of SJW, and also that SJW extracts with low hyperforin content (less than 1\%) have not demonstrated any clinically relevant interactions $(9,51,58,61,63,65-71)$. Gödtel-Armbrust et al (2007) studied the CYP450 induction of LS174T cells by various extracts, commercial products and the purified SJW constituent hyperforin, observing that the content of hyperforin among the commercial preparations of SJW varied 62-fold (range $0.49-30.57 \mathrm{mg} /$ dose) and that the magnitude of the induction correlated statistically significantly with the content of hyperforin in commercial SJW preparations and in dry extracts (69). Mueller et al $(2006,2009)$ reported that the enzyme inducing capacity of the products with low hyperforin content was very weak and a mild induction of CYP3A is not considered clinically relevant $(65,66)$. Another study in healthy volunteers also demonstrated that SJW extract with low hyperforine content does not change the pharmacokinetics of alprazolam, caffeine, tolbutamide and digoxin or midazolam (67). This variability may be the reason for the contraversial findings observed in the literature about the interaction of some drugs with SJW, like alprazolam or midazolam. Some publications demonstrate interaction, whereas some state that there is no interaction.

It was also demonstrated that the pharmacogenetic predisposition was important to the occurence of a Hypericum-drug interaction; due to the environmental and genetic factors, a significant interindividual variability in the induction of CYP3A4 activity among subjects was reported (72).

In summary, it will be wise to recommend that those who are under drug therapy should not take SJW, or if they are regu- 
larly taking it, they should be aware that the efficacy of their conventional treatment may be reduced during concommitent therapy. This type of interactions may have serious clinical consequences for anticoagulant, antiepileptic, antiretroviral, immunosuppressant (cyclosporine and tacrolimus) and anticancer drugs $(9,13)$. Decreased blood trough concentrations of cyclosporine have been observed in patients who were also taking SJW and this was associated with transplant graft rejection in all of these cases (18).

SJW can also have pharmacodynamic interactions, namely synergistic effects with some CNS drugs, especially when combined with drugs that enhance serotonin (5-HT) signalling in the brain. It is used in the treatment of mild to moderate depression, however, it should be rememebered that it may interact with other antidepressant drugs used by the patient. SJW acts by inhibiting the reuptake of monoamines including serotonin, noradrenalin and dopamine, and the amino acid neurotransmitters gamma-aminobutyric acid and glutamate $(1,21,73)$. Thus, there may be an interaction of SJW with other serotonin reuptake inhibitors such as paroxetin, sertaline, venlafaxine, and nefozodone, resulting in symptoms of central serotonin syndrome. This syndrome is characterized by a combination of the following symptoms: confusion, agitation, tremor, diaphoresis, hyperreflexia, nausea, diarrhea, lack of coordination, coma, and / or flushing. For example, mania was observed in a young man taking both SJW and sertaline. A similar interaction may be observed with concommitant use of buspiron and SJW; there is a case report about a woman who experienced hypomania after adding SJW and ginkgo to her regimen of buspirone and fluoxetine (9). A similar type of interaction was also observed with antimigraine drug eletripan; serotonin syndrome and rhabdomyolysis induced by concommitant use of eletripan (an antagonist of $5-\mathrm{HT}_{1 \mathrm{~B}}$ and $5-\mathrm{HT}_{1 \mathrm{D}}$ receptors), fluoxetine and SJW has been reported for a young woman.

\section{Ginger (Zingiber officinale)}

Ginger has prokinetic properties and is used as an antispasmotic and also as an antiemetic agent; its antiemetic effect was demonstrated by clinical studies (21). It is also a traditional medicine against dyspepsia (13). Since it has the potential to accelarate gastric emptying, there is the probability that it may change the bioavailability of sustained release products.

Concomitant intake of ginger was demonstrated to decrease the oral bioavailability (Cmax) and $\mathrm{AUC}(0-\mathrm{t})$ by $70.9 \%$ and $63.1 \%$, respectively), of cyclosporine in rats, probably by interfering its absorption in the intestines (74).

Most of the interactions of ginger with conventional drugs are pharmacodynamic interactions. Ginger was demonstrated to have antithrombotic activity and to prolong bleeding time. There have been a number of investigations resulting in conflicting opinions on the effect of ginger on hemostasis, specifically, platelet inhibition. Under in vitro conditions, ginger inhibits platelet aggregation by inhibiting thromboxane generation via the arachidonic acid (AA) pathway (75). Koo et al (2001) studied this effect in comparison to Aspirin and observed that it inhibited the AA-induced platelet release reaction in a similar dose range as Aspirin (75). However, this antiplatelet effect was not reproducible in human studies. It is also reported to increase fibrinolytic activity (76). Jiang et al
(2005) studied the effect of 7 days of pretreatment with ginger on the anticoagulant effect of warfarin in healthy males and reported that ginger had no effect on the clotting status or on the pharmacokinetics or pharmacodynamics of warfarin (77). However, there are case reports about its interaction with anticoagulant and antiplatelet agents. There is a case report about a 76-year-old white European woman on long-term phenprocoumon therapy with an INR within the therapeutic range (78). She was admitted to the hospital because of epistaxis and an INR $>10$. The patient had a history of severe mitral valve insufficiency, atrial fibrillation, hypertension, chronic heart failure, and osteoporosis. A detailed history revealed a regular ginger intake (pieces of dried ginger, tea from ginger powder) during several weeks before the bleeding incident occurred. The INR returned to the normal range after ginger was stopped and vitamin $\mathrm{K}$ was given. A similar case was reported by Lesho et al (2004) where the patient was on warfarin therapy and was consuming ginger (79). She came to the emergency department because of hematuria and gingival bleeding. After the patient stopped all ginger consumption, and the excessive anticoagulation was partially reversed with intravenous vitamin K, INR values returned to normal. The authors suggest that the increased INR in the patient was due to an interaction between ginger and warfarin involving either the intestinal or hepatic P450 enzyme system.

It was also demonstrated to potentiate the anti-platelet aggregation effect of nifedipine in normal volunteers and hypertensive patients (80).

Shalansky et al (2007) carried out a longitudinal study in humans and observed that the use of complementary or altenative medicine by patients receiving warfarin is common, and consumption of co-enzyme Q-10 or ginger appeared to increase the risk of bleeding in this population (81). Thus, it would be wise not to use it concommitantly with anticoagulant and antithrombotic agents such as warfarine, ticlopidin, aspirin and the like.

Ginger is known to possess hypolipidemic, antioxidant and hepatoprotective properties (82). Thus, a study was carried out in rats to investigate the combined effect of ginger extract (GE) and atorvastatin on lipid profile and on atorvastatin-induced hepatic injury (83). Ginger and atorvastatin were observed to have additive effects in lowering plasma cholesterol levels. Ginger also appeared to decrease the hepatotoxic effects of atorvastatin, and the authors suggest that the combination regimens containing ginger and low dose of statins could be advantageous in treating hypercholesterolemia.

\section{Ginkgo (Ginkgo biloba)}

Ginkgo (Ginkgo biloba leaves) is accepted as a vasodilator and an antiplatelet product and is used mainly for memory deficits, for the treatment of dementia, vertigo, peripheral vascular diseases and tinnitus $(3,9,10,12)$. It is considered to be a relatively safe herbal drug, with few side effects. However, the active chemicals in gingko (ginkgolide, bilobalides etc) have antiplatelet activity and are platelet activating factor (PAF) antagonists, thus there is a concern that it may increase bleeding time on long term use, especially during the postoperative period $(9,10,12,25,84-86)$. Thus, it is generally accepted that the concurrent use of Ginkgo biloba with anticoagulant drugs such as warfarin or antiplatelet agents like aspirin or other NSAI 
drugs (rofexocib or ibuprofen) represents a serious health risk $(3,8,9,10-12,17,21)$. There are some case reports about patients who had postopeative haemorrhage, spontaneous intracranial bleeding or hyphema due to ingeston of herbal medicines containing Ginkgo biloba in addition to their conventional drug therapies $(12,85)$. To give a few examples, spontaneous bleeding from the iris into the interior chamber of the eye in a patient who was taking $325 \mathrm{mg}$ of Aspirin per day has been reported. Bleeding was linked to Ginkgo biloba intake of $80 \mathrm{mg}$ per day for one week prior to the onset of symptoms (86). Parietal hemorrhage was reported in a 78 years old woman who had been on warfarin therapy for the last 5 years and who experienced hemorrhage 2 months after she started taking Ginkgo biloba. There is another case report about persistent bleeding following total hip arthroplasty; the patient happened to be self medicating with ginkgo and bleeding stopped 6 weeks after ginkgo intake was stopped (87). A case of post-laparoscopic cholecystectomy bleeding in a patient taking Ginkgo biloba was also reported (88).

Accordingly, it is recommended that people who are taking drugs that effect coagulation and/or platelet function or people who will undergo surgery should not be using Ginkgo $(9,21,86,89)$.

However, recent reports on this subject do not seem to confirm that Ginkgo biloba increases bleeding time or augments the effect of anticoagulants or antiplatelet agents. Accordingly, it has been demonstrated that Ginkgo biloba extract did not change the bleeding time when combined with ticlopidine (90). Moreover, Kim et al (2010) studied the effect of a single $80 \mathrm{mg}$ dose of Ginkgo biloba on the antiplatelet effect of ticlopidin in Korean men and reported that Ginkgo biloba did not change the bleeding time (91). It was not found to be associated with additional antiplatelet effects compared with the administration of ticlopidine alone, nor did it change the pharmacokinetics of the antiplatelet drug. In another study it was observed that coadministration of Ginkgo biloba either with cilostazol or clopidogrel did not enhance antiplatelet activity compared with individual agents, but Ginkgo biloba potentiated the bleeding time prolongation effect of cilostazol (92). According to Ryu et al (2009) the combined therapy with Ginkgo biloba and cilostazol showed enhanced anti-thrombotic effects in an in vivo pulmonary embolism model and arterial thrombosis model without having a significant effect on the bleeding time (93). They concluded that the additive interaction of these products may be beneficial in the clinical use. Jiang et al (2006) reported that concommitent intake of Ginkgo biloba did not change the pharmacokinetics or pharmacodynamics of warfarin (94). Wolf (2006) administered aspirin with various Ginkgo biloba extracts for 7 days and bleeding time, coagulation parameters and platelet activity in response to various agonists were determined (95). He concluded that co-administration of ASA and Ginkgo biloba extract does not constitute a safety risk, including an elderly patient population undergoing treatment with Ginkgo biloba extract.

After reviewing the literature some investigators have stated that "available evidence does not demonstrate that extract of Ginkgo biloba causes significant changes in blood coagulation parameters" $(9,13,96,97)$.
There appears to be a dose related effect since review of the literature points to the fact that patients who consumed a daily dose of $120 \mathrm{mg}$ or more appeared to have a higher incidence of prolonged bleeding, hyphema, subphrenic hematoma, and intracranial hemorrhage (10). Besides, in the above studies where no interaction was observed (90-93), Ginkgo biloba was given as a single dose, whereas case reports state that the patients were consuming Ginkgo biloba for a long period of time. We believe that acute or chronic use of a product should be taken into consideration while evaluating its pharmacologic effects and its interaction with other drugs.

In summary, it is evident that although there are contraversial reports about the interactions of Ginkgo biloba with antithrombotic and anticoagulant drugs, it will be prudent not to use it in patients who are being treated with anticoagulats or who will undergo surgery.

There are many studies investigating the effect of Ginkgo biloba on CYP enzymes and P-gp. Some of them indicate that chronic use of Ginkgo biloba may possibly inhibit P-gp or induce CYP2C19 and CYP3A4, thus changing the pharmacokinetics of concommitantly used drugs such as alprazolam and midazolam or digoxin. However, reports on the effect of Ginkgo biloba on other CYP enzymes are contraversial; while some investigators stated that it does not have a significant effect on CYP enzymes, others state that it might have an inducing effect $(13,98-107)$.

Yeung et al. (2009) have investigated the effect of ethanol extracts of Ginkgo biloba for its capability to induce CYP3A4, 3A5 and $\mathrm{ABCB} 1$ (P-gp) gene expression via PXR signaling pathway using HepG2 cell based reporter gene assay (100). It was identified as an afficacious PXR agonist and it was also observed to induce CYP3A4 reporter gene. They recommend that caution should be taken when it is used in combination with prescribed drugs metabolized by CYP3A4 or are substrates for P-gp. Hellum and Nielsen (2008) studied the inhibitory effect of varios herbals on CYP3A4 and P-gp under in vitro conditions in Caco-2 cells and observed that Ginkgo biloba had a strong inhibitory effect on P-gp (101). They observed ed no correlation between the herbs inhibitory potentials towards CYP3A4 and P-glycoprotein activities. They also studied the induction capacity of some herbal drugs on CYP1A2, CYP2D6, CYP2C19, CYP2E1 and CYP3A4 metabolic activities in cultured human hepatocytes and reported that Ginkgo biloba may exert opposite and biphasic effects on CYP1A2, CYP2C19, CYP2E1 and CYP2D6 metabolic activities. Induction of CYP1A2, CYP2C19, CYP2E1 and inhibition of CYP2D6 were found at low concentrations; the opposite was observed at high concentrations $(64,102)$. They reported that inducing effect of Ginkgo biloba was close to that of SJW. This observation might explain the contraversial results reported by different investigators.

Repeated ingestion of Ginkgo biloba extract by healthy Chinese volunteers was reported to increase talinolol bioavailability significantly without significant changes in elimination halflife and the time to $C_{\max }$ (98). These findings suggest that longterm use of Ginkgo biloba extract significantly influences talinolol disposition in humans, most probably by affecting the activity of P-gp and/or other drug transporters. 
Ginkgo biloba was demonstrated to increase the metabolism of the antiepileptic drugs valproic acid and phenytoin, both of which are substrates of CYP2C19. There is a case report about an epileptic patient who had been treated with valproic acid and phenytoin, and who died after fatal seizures (21). It appeared that this was a result of herb-drug interaction since he happened to be taking herbal supplements including ginkgo and at autopsy, had subtherapeutic serum concentrations of these antiepileptics. Thus, it was recommended that patients taking antiepileptic drugs should be cautioned against using gingko preparations concommitently (9). Similar observations were reported for tolbutamide. The effect of chronic administration of ginkgo biloba on the pharmacokinetics of tolbutamide was investigated in rats (103), and also in healthy male volunteers (104). It was observed to attenuate the hypoglyceamic effect of tolbutamide (probe for CYP2C9) by increasing its rate of metabolism and decreasing its plasma concentrations. On the other hand, it increased the area under the curve (AUC) for midazolam (a probe for CYP3A4) and decreased its oral clearence significantly (104). Diazepam is also a substrate of CYP2C19, but Zuo et al (2010) reported that chronic administration of Ginkgo biloba (120 mg twice a day) to healthy volunteers for 28 days did not change the pharmacokinetics of diazepam, they did not observe any adverse effects due to the combined use (105).

Tang et al (2007) reported that Gingko biloba pretreatment increases the CYP1A2 metabolic activity and thus the clearance of theophylline in rats (106). Taki et al (2011) studied blood coagulation parameters and hepatic cytochrome P450 enzyme (CYPs) levels in mice after administration of Ginkgo biloba or various active components of Ginkgo biloba orally for 5 days and reported that Ginkgo biloba and ginkgolide B have no influence on blood coagulation in vivo, and that Ginkgo biloba attenuates the anticoagulat action of warfarin via induction of hepatic CYPs by bilobalide (107).

Oral coadministration of Ginkgo biloba was reported to decreases the bioavailability of cyclosporin significantly by decreasing its absorption (107). It is recommended that drugs that are P-gp substrates be monitored when co-administered with ginkgo, because some authors reported high between subject variability in bioavailability of digoxin, after 8 days of ginkgo ingestion (13).

In order to explain these contraversial reports, it was suggested that the inhibitory capacity of herbal products varied depending on the concentrations of the model substrate and the herbal extract, as well as the identity of the model substrate, as demonstrated by the varied effects of CYP3A4 enzymatic activity with different model substrates (109).

Another interesting interaction of ginkgo is that with risperidone. A young man who was being treated with risperidon for schizophrenia started taking Ginkgo biloba for tinnitus and experienced priapism. Risperidon has serotonergic, dopaminergic and alpha-adrenergic antagonistic properties and it is mainly metabolized by CYP3A4 and CYP2D6 enzymes that are known to be inhibited by Ginkgo biloba. Authors attributed priapism to the increased plasma levels of risperidone due to the inhibition of its metabolism by Ginkgo biloba (110). Since both drugs have vasodilator effects, priapism may also have been the result of an additive or synergistic interaction. Ginkgo biloba is also known to interact with thiazide diuretics; there are case reports about patients who developed increased blood pressure while taking these two drugs concurrently (10).

Ginkgo biloba may also interact wih the antidepressant trazodone, a serotonin antagonist and reuptake inhibitor, resulting in coma (111). When this patient was given an IV dose of flumazenil, a specific antagonist of benzadiazepine receptors, she awoke immediately. Since trazone did not act on benzodiazepine receptors, it was concluded that Ginkgo biloba was acting on these receptors and investigation of the sedative effects of Ginkgo biloba was recommended.

\section{Ginseng (Panax ginseng, Asian ginseng or Korean ginseng)}

Ginseng is reported to be the fifth most commanly used herbal drug in the USA. Active components of different Ginsengs are different and thus wide variations exists among ginseng products. Asian (or Korean) ginseng (roots of Panax ginseng) is generally standardized to ginsenosides (a group of compounds known as steroidal saponins) and is used for various indications including erectile dysfunction, prevention of cancer, to enhance physical function, and improve cognitive functions; it is advertised as an immune system stimulant. In Chinese medicine it is also used for various cardiovascular diseases $(7,14)$. Panax ginseng appears to be well tolerated, however caution is advised about concommitant use with warfarin, oral hypoglyceamic drugs, insulin and phenelzin (111).

Co-administration of ginseng with other drugs may cause drug interactions. It was reported that it did not appear to have any effect on CYP enzymes, except for CYP2D6, which it may inhibit in the elderly (13). Pharmacokinetic interaction of Panax ginseng with midazolam (CYP3A4), caffeine (CYP1A2), chloroxazone (CYP CYP2E1) and debrisoquine (CYP2D6) was studied in healthy young or elderly volunteers and no statistically significant interaction was observed, demonstrating that ginseng does not have a significant effect on drug metabolism (13). However, previous reports on ginseng-drug interactions have been controversial and confusing. In a recent study carried out using HepG2 cells, it was observed that deglycosylated ginsenosides, some of which are putative ginsenoside metabolites, were more potent inducers of CYP1A1, CYP1A2 and CYP3A4 than glycosylated ginsenosides (112). They concluded that ginsenoside metabolites may partially account for ginseng-drug interactions. Since ginsenosides are deglycosilated by enterobacteria before they enter the circulation, differences in the composition of intestinal bacteria (present in different individuals and populations) and the extent of deglycosylation of the ginsenosides could be a contributing factor to the inconsistencies observed in previous clinical and pre-clinical studies with regard to ginseng-drug interactions.

Ginseng extracts was demonstrated to modulate multidrug resistance efflux transporters in a number of cancer cell lines, but not in caco-2 cell model 811 (13).

A potential therapeutic use of Ginseng is to lower postprandial blood glucose in both patients with type 2 diabetes mellitus and without diabetes, but this may result in unintended hypoglycemia $(3,21)$. 
Ginseng has been reported to interact with anticoagulant-antithrombotic drugs (33). It has been demonstrated to inhibit platelet aggregation, however, decreased INR in a patient taking warfarin was reported. In another study American ginseng was reported to decrease the anticoagulant effect of warfarin (probably due to a pharmacokinetic interaction) (9).

A 47 year old man with a mechanical heart valve had been stabilized while receiving warfarin for 5 years, but became destabilized following administration of ginseng. INR values of the patient had decreased due to ginseng ingestion, but returned back to normal 2 weeks after discontinuation of ginseng therapy. Due to this property, it is recommended that concommitent use with warfarin, heparin or other anticoagulants, as well as antiplatelet agents like aspirin and other NSAI drugs with ginseng should be avoided (12, 21, 25). However, interaction of warfarin with ginseng was studied by observing the prothrombin time and the INR in 25 newly diagnosed ischemic stroke patients who did not have a history of taking warfarin. They reported that ginseng did not change the warfarin effect (113). It is proposed that these contraversial reports on the possible interaction between warfarin and ginseng may depend on the pharmacogenetic disposition of the patients (13).

A young man with chronic myelogenous leukemia was being treated with imatinib when he experienced hepatotoxicity. Patient's only lifestyle modification prior to the diagnosis of hepatotoxicity was daily ingestion of Panax ginseng via energy drinks for the past 3 months. After discontinuation of imatinib and the energy drink, he recovered. Imatinib is known to cause hepatotoxicity after a few years of use. In vivo, ginseng is known to inhibit CYP3A4, the primary enzyme involved in the metabolism of imatinib and in this case it is proposed that hepatotoxicity was due to the accumulation of imitanib because of inhibition of its metabolism by ginseng (114).

It was also reported to decrease the effect of loop diuretics, antihypertansives, anxiolytics, alcohol, antidepressants, MAO inhibitors, mood stabilizers and antiestrogens (10). But still, available clinical data suggests that the potential for ginsengdrug interactions is low.

Ginseng has a structure similar to steroids and may have additive effects with estrogens and corticoids. Thus, it is recommended that they should not be used together $(4,13,21,25)$.

In summary, it is claimed that ginseng does not have an important interaction with other drugs, except for the interaction with the antidepressant drug phenelzine; it was reported to have induced mania if taken concomitantly with phenelzine (9). Nevertheless, it is recommended to discontinue Ginseng use at least 7 days prior to surgery $(10,12)$ because it is reported to have hypoglycaemic and antiplatelet properties, inhibits platelet activating factor and prolongs bleeding time, thus increasing the risk of bleeding disorders with drugs known to increase bleeding time (ie. anticoagulants, NSAIDs, platelet inhibitors) $(9,10)$.

\section{Echinaceae}

Three kinds of Echinaceae exists: E. Angustifolia, E. Pallida and E. Purpurea. Extracts of echinacea consists mainly of lipophilic constituent alkamides with immunomodulatory properties (13).
It is one of the most widely used over-the-counter herbal medicines and Echinaceae species are used for the prophylaxis and treatment of viral, bacterial and fungal infections, especially those of the upper respiratory tract $(10,12,13)$. It has also been recommended for treating abscesses, burns, eczema, skin wounds, varicose leg ulcers and some cancers (25).

There are a number of studies which report that Echinaceae has only a weak inhibitory effect on CYP enzymes and transport proteins. In an in vitro study in Caco-2 cells, it was demonstrated that the inhibitory effect of various Echinaceae extracts on CYP3A4 and P-gps showed large variability depending on the total alkamide content of the extract (101). Gorski et al (2004) studied the effect of Echinaceae on various CYP enzymes in healthy human volunteers using different probe drugs, namely caffein (CYP1A2), tolbutamide (CYP2C9), dextromethorphan (CYP 2D6) and midazolam (CYP3A4), and observed that it significantly reduces the clearence of only caffein (CYP1A2) and tolbutamide (CYP2C9). They also reported that there was a considerable between subject variability for this inhibitory effect on CYP enzymes (115). On the other hand, bioavailability of midazolam (CYP3A4) was observed to be increased due to a slight inhibition of its presystemic elimination. They concluded that the type of drug interactions observed between echinaceae and other CYP3A substrates will be dependent on the relative extraction of drugs at hepatic and intestinal sites, recommending to be cautious when echinacea is coadministered with drugs dependent on CYP3A or CYP1A2 for their elimination. In another study in healthy human volunteers, echinaceae was reported to have a slight inhibitory effect only on CYP1A2 activity (caffein metabolism) (27), whereas in an in vitro study using total RNA isolated from the rat liver tissue, Echinaceae ethanolic extract was demonstrated to potently inhibit the expression of CYP3A1/2 and that it can also induce of CYP1A1, CYP2D1 (116).

In a recent study in human volunteers, lopinavir was administered in combination with ritonavir and although Echinaceae was observed to induce CYP3A, it did not alter lopinavir concentrations, most likely due to the presence of the potent CYP3A inhibitor ritonavir $(117,118)$. In a study with Caco-2 cells, Hansen and Nilsen (2009) observed that Echinaceae had an in vitro inhibitory potential for CYP3A4 mediated metabolism and P-gp efflux transport (119). In the same study echinacea was observed to decrease digoxin efflux in a dose dependent manner and the authors stated that although the effects of Echinaceae purpurea on systemic P-gp mediated drug transport are probably limited, an influence on drug bioavailability can not be excluded. In fact in a previous human study, echinacea was reported not to change digoxin bioavailability, indicating that it does not have an effect on intestinal P-gps (13). However, it should be remembered that these different observations can be due to the different plant species and the part of plant used, as well as to different dosages and duration of treatment $(9,13)$. In conclusion, studies in general state that Echinaceae does not have any significant effect on CYP enzymes and a weak cytochrome P450 inhibition is unlikely to be of clinical relevance $(120,121)$.

It should also be stated that literature reports on the potential of Echinaceae to interact with other drugs are unequivocal and comparisons between studies are difficult as the phytochemi- 
cal composition of the preparations examined is rarely assessed. It should also be remembered that since there are no industry standardization requirements, differences in the relative concentrations of individual alkylamides between preparations could alter the potential for interactions (122).

Echinaceae is accepted to have some immunostimulatory effects $(10,12,123)$ and experts warn against the concomitant use of echinacea with immunosuppressive drugs, since there is the probability that it may diminish their effects. Therefore patients who may require perioperative immunosuppression, such as those awaiting organ transplanation, as well as patients with autoimmun conditions or HIV infection should avoid using echinacea.

In fact, long term use (longer than 8 weeks) of echinaceae is reported to result in immunosuppression and thus may cause post surgical complications such as delayed wound healing and opportunistic infections $(10,12,17)$.

Echinaceae was also reported to have a hepatotoxic effect if used beyond 8 weeks and therefore should not be used with other known hepatoxic drugs, such as acetaminophen, anabolic steroids, amiodarone, methotrexate, and ketoconazole. It should also be avoided by patients with preexisting liver dysfunction $(10,12,21,25)$

\section{Ephedra (Ma huang)}

Ephedra is used to promote weight loss, increase energy and treat respiratory tract ailments such as asthma. Its commercial preparations are usually standardized to a fixed ephedrine content, one of its alkoloids. It is known to have sympathomimetic effects and thus causes dose-dependent increases in heart rate and blood pressure. Sympathomimetic effects of ephedra may cause various cardiovascular adverse effects including fatal cardiac complications and central nervous system complications. Thus, it has been reported that although ephedrine is used as a first-line therapy for intraoperative hypotension and bradicardia, the unsupervised preoperative use of it may cause certain concerns, like vasoconstriction and in some cases vasospasm of coronary and cerebral arteries, which may result in myocardial infarction and thrombotic stroke. Since halothane is known to sensitize the myocardium to ventricular arrhythmias caused by exogenous catecholamines, patients who have consumed ephedra and later anesthetized with halothane may be at risk of developing intraoperative ventricular arrhythmias (12).

Longterm use of ephedra may result in tachyphylaxis from depletion of endogenous catecholamines which may cause perioperative hemodynamic instability. These situations should be treated with sympathomimetics with a direct effect. In summary, it was suggested that patient using ephedra should discontinue use at least 24 hours prior to surgery (12).

Ephedra should not be used with monoaminoxidase inhibitors; this combination may cause life-threatining hyperpyrexia, hypertension and coma.

\section{Valerian (Valeriana oficinalis)}

Valerian is used as a sedative, especially in the treatment of insomnia and it is reported that almost all herbal sleep aids contain valerian (12). It is also used widely in Turkey. Valerian causes a dose dependent sedation and this effect was reported to be mediated through modulation of GABA neurotransmission and receptor function, thus it should be expected to have additive effects with anesthetic drugs, sedative medication and adjuvants midazolam. This may be dangerous in the elderly since it may increase the risk of falls. It was recommended that caution must be exerted in prescribing benzodiazepines and other sedatives to elderly people using valerian (86). A case of a patient self-medicated with Valeriana officinalis L. and Passiflora incarnata L. while he was on lorazepam treatment was reported. Handshaking, dizziness, throbbing and muscular fatigue were observed within the $32 \mathrm{~h}$ and his medical history revealed a generalized anxiety disorder and medicinal plant consumption but no neurological disorder. It was proposed that the active principles of Valerian and passionflower might have increase the inhibitory activity of benzodiazepines binding to the GABA receptors, causing severe secondary effects $(124,125)$. Although it has been claimed not to interact with alcohol, some do warn against its use with alcohol. Accordingly, it was suggested that the dose of valerian should be tapered under medical supervision during several weeks before surgery in order to avoid any unwanted interaction with the anesthetics (126). Dalla Corte et al (2008) have reported that combined use of valerian and haloperidol might increase the risk of oxidative damage in the liver (127). However, acute withdrawal of valerian should be avoided since there is the danger of abstinence syndrome after long term use. Both animal and human studies suggest that valerian does not have a significant effect on CYP enzymes (128).

\section{Cranberry (Vaccinium macrocarpon)}

Cranberry is used to prevent urinary tract infections, and has some antibacterial and anticancer activities. Cranberry juice is also used as a laxative in Western countries. Cranberry juice is not marketed in Turkey, but dry fruit is consumed as a snack. There is an interesting case report about the interaction of warfarin with cranberry juice (129). A patient who was on warfarin therapy experienced an increase in INR on 2 different occasions after consuming cranberry juice for a few days. Thus, we suggest that people who are treated with anticoagulants or who take antithrombotic agents should be aware that consumption of large quantities of cranberry may result in an unwanted interaction, increasing the bleeding time.

\section{CONCLUSION}

It is evident from the data given above that due to a worldwide rise in the use of dietary supplements and/or herbal preparations, the incidence and severity of herb-drug interactions are increasing. This poses a serious problem in the treatment of patients, and represents a serious and under-recognized hazard in clinical care, especaially for those using drugs with narrow therapeutic indices. More clinical data regarding herbdrug pharmacokinetic and/or pharmacodynamic interactions are needed to make informed decisions regarding patient safety. However, we should be very careful when interpreting the literature data since the findings from in vitro studies or animal studies do not always correlate with the situation in the clinic, or minor effects observed in clinical studies do not have to be clinically relevant. Efficacy and safety of herbal products should be obtained by well designed clinical trials, pre-marketing approval regarding safety and strict post-marketing surveillance (4). 


\section{Bitkisel ilaçlar ve ilaç etkileşmeleri}

Tek bir bitkiyi, ya da birbirinin etkisini tamamladığı düşünülen birkaç bitki karışımını içeren herhangi bir ürün Bitkisel ilaç olarak tanımlanmaktadır. Bitkisel ürünler doğal olmaları nedeni ile genelde zararsız kabul edilmektedirler, ancak bunların da ciddi yan etkileri olabilir veya diğer doğal ürünler ya da hastanın kullandığı diğer ilaçlarla etkileşebilirler. Bu etkileşmeler özellikle terapötik indeksi dar olan ilaçlar açısından önemlidir.

Bu çalışmada literatür taraması yapılarak bazı sık kullanılan bitkisel ürünler (St John's wort, ginkgo biloba, ginseng, ginger(zencefil), sarmısak, ekinase, efedra, ve valerian) ile konvansiyonel ilaçlar arasındaki farmakokinetik ve farmakodinamik etkileşmeler derlenmiştir. Farmakokinetik etkileşmelerin en sık görüleni sitokrom P450 enzimlerinin ve P-glikoproteinlerin bitkisel ürün tarafından indüksiyon veya inhibisyonundan kaynaklanan etkileşmelerdir. Bunların sonucunda konvansiyonel ilaçların emilimi ve/veya eliminasyon hızı değişeceği için etkinliğinde de değişme olacaktır. Örneğin, St. John's wort CYP enzimlerini ve P-glikoproteinleri güçlü biçimde indüklediği için bu enzimlerin substratı olan birçok ilacın kan düzeylerini, dolayısı ile etkinliğini değiştirmektedir.

Farmakodinamik etkileşmeler aditif veya sinerjist etkileşme şeklinde olabilir ve bunun sonucunda ilacın etkisi artar ya da toksisite görülebilir. Örneğin St John's wort hastanın kullandığı diğer antidepresan ilaçların santral sinir sistemi etkinliğini artırıp serotonin sendromuna neden olabilir. Ginseng, ginkgo, sarımsak, zencefil gibi ürünlerin antikoagülan veya antitrombatik ilaçların etkinliğini artırarak kanamalara neden olabildiği bildirilmiştir.

Bazı hallerde de bitkisel ürün diğer ilaçlarla antagonist etki gösterebilir ve bu durumda onların etkinliğini azaltarak tedavinin yetersiz kalmasına yol açabilir. Kısaca, bitkisel ürün kullanmaları halinde bunların kullandıkları diğer ilaçlarla etkileşebileceği ve tedavilerini olumsuz etkileyebileceği konusunda hastaların uyarılmaları gerekmektedir.

ANAHTAR KELIMELER: St John's wort, sarmısak, ginkgo, zencefil, ginseng,

Special care should be taken with certain patient groups such as those receiving cancer chemotherapy or antiretroviral therapy, or patients that are treated for cardiovascular diseases (especially those using anticoagulant or antithrombotic drugs); they should be advised against using alternative therapy. In a recent study it has been reported that approximately 180 dietary supplements have the potential to interact with warfarin, and more than 120 may interact with aspirin, clopidogrel, and dipyridamole (33).

A large number of herbal remedies (e.g. garlic, mistletoe, Essiac, Lingzhi, and astragalus) are used by cancer patients for treating the cancer and/or reducing the toxicities of chemotherapeutic drugs. Although some herbal medicines have shown potentially beneficial effects on cancer progression and may ameliorate chemotherapy-induced toxicities, it should be remembered that there is no or weak scientific basis for the clinical use of these herbal medicines in cancer management and almost none of these plant medicines have been tested in rigorous clinical trials $(129,130)$. Further studies are warranted to investigate the efficacy and safety profiles of herbal medicines commonly used by cancer patients $(34,51)$. It should be stressed that induction and/or inhibition of CYP enzymes and/or transport proteins is considered an important mechanism for the interaction between anticancer drugs and herbal medicines, especially SJW (60). On the other hand, pharmacodynamic interactions are reported to be an increased risk of CNS system related effects, hepatotoxicity and bleeding, among others. Clinicians who are treating cancer patients should be vigilant if the patient is also using alternative medicine and if so, dose monitoring of pharmacological effects and plasma drug levels should be carried out to avoid toxicity and ensure adequate anticancer chemotherapy. Health care professionals should question their patients on their use of alternative therapy, especially those whose disease is not responding to treatments as expected, and urge patients to avoid herbs that could confound their cancer care.

Presurgical patients are another important population that has to be warned against use of herbal medicines because morbidity and mortality associated with herbal medications may be more likely in the perioperative period because of the polypharmacy and physiological alterations that occur. Patients who will undergo surgery should be advised to stop taking any altenative therapy (herbal or otherwise). In order to decrease the unwanted reactions, queries regarding the use of herbal supplements and other over the counter medication should be the standart part of routine preoperative screening, in addition to questions regarding the use of conventional medications, tabacco, alcohol and drugs. This is very important, since many of the herbal products may prolong bleeding time and/or they may intearct with anticoagulant or antithrombotic drugs, as explained above. Thus patients are advised to stop using alternative therapy at least two weeks prior to surgery.

Health care providers should be vigilant of potential herbdrug interactions and adopt proper strategies to minimize them. It is also important that the clinicians, and medical doctors in general, should be give an effective education about herbal drugs and other dietary supplements; and should be trained to ask the patients if they are using altenative medicines or dietary supplements, and document their responses in the medical record which can help reduce the chance of unwanted serious interactions $(3,10,18)$. Patients as well should be trained to tell their physicians about all of the products they are consuming besides their prescribed medicines. They should also be aware that, in general, potentially limited standardization and quality control, and somewhat circumscribed regulation, may result in variability in content, efficacy, and potential contamination of herbal remedies. 


\section{REFERENCES}

1. Bent S, Ko R. Commonly used herbal medicines in the United States: A review. Am J Med 2004; 116: 478-485.

2. Stein K. Herbal supplements and prescription drugs. J Amer Dietetic Ass 2000; 100: 412.

3. Graham RE, Gandhi TK, Borus J, Seger AC, Burdick E, Bates DW, Phillips RS, Weingart SN. Risk of concurrent use of prescription drugs with herbal and dietary supplements in ambulatory care. In: Advances in Patient Safety: New Directions and Alternative Approaches Vol. 4: Technology and Medication Safety. editors: Henriksen K, Battles JB, Keyes MA, Grady ML. Rockville (MD): Agency for Healthcare Research and Quality (US), 2008.

4. Tachjian A, Maria V, Jahangir A. Use of herbal products and potential interactions in patients with cardiovascular diseases. J Amer Coll Cardiol 2010; 55: 515-25.

5. Mohamed-Eslam FM, Frye RF. Effect of herbal supplements on drug glukuronidation. Review of clinical, animal, and iv vitro studies. Planta Med 2011; 77: 311-21.

6. Gonzales-Stuart A. Herbal product use by older adults. Maturitas 2011; 68: 52-5.

7. Izzo A, Ernst E. Interactions Between Herbal Medicines and Prescribed Drugs. Drugs 2009; 69: 1777-98.

8. Messina BAM. Herbal supplements: Facts and MythsTalking to your patients about herbal supplements. J PeriAnesthesia Nursing 2006; 21: 268-78.

9. Saw JT, Bahari MB, Ang HH, Lim YH. Potential drugherb interaction with antiplatelet/anticoagulant drugs. Complement Ther Clin Pract 2006; 12: 236-41.

10. Mehta DH, Gardiner PM, Phillips RS, McCarthy EP. Herbal and dietary supplement. Disclosure to health care providers by individuals with chronic conditions. J Altern Complement Med 2008; 14: 1263-69.

11. Ang-Lee MK, Moss J, Yuan CS. Herbal medicines and perioperative care. JAMA 2011; 286: 208-16.

12. Colalto $C$. Herbal Interactions on absorption of drugs: Mechanism of action and clinical risk assessment. Pharmacol Res 2010; 62: 207-27.

13. Valli G, Giardina EG. Benefits, adverse effects and drug interactions of herbal therapies with cardiovascular effects. J Amer Coll Cardiol 2002; 39: 1083-95.

14. Izzo AA, Di Carlo G, Borrelli F, Ernst E. Cardiovascular pharmacotherapy and herbal medicines: the risk of drug interaction. Int J Cardiol 2005; 98: 1-14.

15. Niggemann B, Grüber C. Side effects of complementary and alternative medicine. Allergy 2003; 58: 707-16.

16. Hafner-Blumenstiel $V$. Herbal drug-drug interaction and adverse drug reactions. Ther Umsch 2011; 68: 54-7.

17. Zhou $S$, Zhou Z, Li C, X. Chen $X, Y u$ X, Xue C, Herington A. Identification of drugs that interact with herbs in drug development. Drug Discovery Today 2007; 12: 664-73.

18. Zhou $S$, Gao $Y$, Jiang $W$, Huang $M, X u$ A, Paxton JW. Interactions of herbs with cytochrome P450. Drug Metab Rev 2003; 35: 35-98.

19. Zhou S, Lim LY, Chowbay B. Herbal modulation of Pglycoprotein. Drug Metab Rev 2004; 36: 57-104.

20. Miller LG. Herbal medicinals: selected clinical considerations focusing on known or potential drug-herb interactions. Arch Intern Med 1998; 158: 2200-11.

21. Hu Z, Yang X, Ho PC, Chan SY, Heng PW, Chan E, Duan W, Koh HL, Zhou S. Herb-drug interactions: a literature review. Drugs 2005; 65: 1239-82.
22. Huang SM, Lesko LJ..Drug-Drug, Drug-Dietary Supplement, and Drug-Citrus Fruit and Other Food Interactions: What Have We Learned? J Clin Pharmacol 2004; 44: 559-69.

23. Tarirai C, Viljoen AM, Hamman JH. Herb-drug pharmacokinetic interactions reviewed. Expert Opin Drug Metab Toxicol 2010; 6: 1515-38.

24. Tirona RG, Bailey DG. Herbal product-drug interactions mediated by induction. Br J Clin Pharmacol 2006; 61: 677-81.

25. Abebe $W$. Herbal medication: potential for adverse interactions with analgesic drugs. J Clinical Pharmacy Therap 2002; 27: 391-401.

26. Gurley BJ, Gardner SF, Hubbard MA, Williams DK, Gentry WB, Cui Y, Ang CY. Clinical assessment of effects of botanical supplementation on cytochrome P450 phenotypes in the elderly: St John's wort, garlic oil, Panax ginseng and Ginkgo biloba. Drugs Aging 2005; 22: 525-39.

27. Gurley BJ, Swain A, Williams DK, Barone G, Battu SK. Gauging the clinical significance of P-glycoprotein-mediated herb-drug interactions: comparative effects of St.John's wort, Echinacea, clarithromycin, and rifampin on digoxin pharmacokinetics. Mol Nutr Food Res 2008; 52: 772-9.

28. Chen XW, Serag ES, Sneed KB, Liang J, Chew H, Pan SY, Zhou SF. Clinical Herbal Interactions with Conventional Drugs: From Molecules to Maladies. Curr Med Chem 2011 [In press].

29. Asdaq SM, Inamdar MN, Asad M. Effect of conventional antihypertensive drugs on hypolipidemic action of garlic in rats. Indian J Exp Biol 2009; 47: 176-81.

30. Asdaq SM, Inamdar MN. Pharmacodynamic interaction of captopril with garlic in isoproterenol-induced myocardial damage in rat. Phytother Res 2010; 24: 720-5.

31. Asdaq SM, Inamdar MN. Potential of garlic and its active constituent, S-allyl cysteine, as antihypertensive and cardioprotective in presence of captopril. Phytomedicine 2010; 17: 1016-26.

32. Asdaq SM, Inamdar MN. The potential for interaction of hydrochlorothiazide with garlic in rats.Chem Biol Interact 2009; 181: 472-9.

33. Mousa SA. Antithrombotic effects of naturally derived products on coagulation and platelet function. Methods Mol Biol 2010; 663: 229-40.

34. Yang AK, He SM, Liu L, Liu JP, Wei MQ, Zhou SF. Herbal interactions with anticancer drugs: mechanistic and clinical considerations. Curr Med Chem 2010; 17: 163578 .

35. Hajda J, Rentsch KM, Gubler C, Steinert H, Stieger B, Fattinger K. Garlic extract induces intestinal P-glycoprotein, but exhibits no effect on intestinal and hepatic CYP3A4 in humans. Eur J Pharm Sci 2010; 41: 729-35.

36. Berginc K, Trdan T, Trontelj J, Kristl A. HIV protease inhibitors: garlic supplements and first-pass intestinal metabolism impact on the therapeutic efficacy. Biopharm Drug Dispos 2010; 31: 495-505.

37. Berginc K, Trontelj J, Kristl A. The influence of aged garlic extract on the uptake of saquinavir and darunavir into HepG2 cells and rat liver slices. Drug Metab Pharmacokinet 2010; 25: 307-13.38.

38. Dostalek M, Pistovcakova J, Jurica J, Tomandl J, Linhart I, Sulcová A, Hadasova E. Effect of St John's wort (Hypericum perforatum) on cytochrome P-450 activity in perfused rat liver. Life Sci 2005; 78: 239-44. 
39. Di YM, Li CG, Xue CC, Zhou SF. Clinical drugs that interact with St. John's wort and implication in drug development. Curr Pharm Des 2008; 14: 1723-42.

40. Moore LB, Goodwin B, Jones SA, Wisely GB, SerabjitSingh CJ, Willson TM, Collins JL, Kliewer SA. St. John's wort induces hepatic drug metabolism through activation of the pregnane $X$ receptor. Proc Natl Acad Sci USA 2000; 97: 7500-2.

41. Dürr D, Stieger B, Kullak-Ublick GA, Rentsch KM, Steinert HC, Meier PJ, Fattinger K. St John's Wort induces intestinal P-glycoprotein/MDR1 and intestinal and hepatic CYP3A4. Clin Pharmacol Ther 2000; 68: 598-604.

42. Wang Z, Gorski JC, Hamman MA, Huang SM, Lesko LJ, Hall SD. The effects of St John's wort (Hypericum perforatum) on human cytochrome P450 activity.Clin Pharmacol Ther 2001; 70: 317-26.

43. Markowitz JS, DeVane CL.The emerging recognition of herb-drug interactions with a focus on St. John's wort (Hypericum perforatum). Psychopharmacol Bull 2001; 35: 53-64.

44. Markowitz JS, Donovan JL, De Vane CL, Robin MT, Ruan Y, Wang J-S, Chavin KD. Effect of St John's wort on drug metabolism by induction of cytochrome P450 3A4 enzyme. JAMA 2003; 290: 1500-4.

45. Kliewer SA. The Nuclear Pregnane X Receptor Regulates Xenobiotic Detoxification. J Nutr 2003; 133: 2444S-7S.

46. Staudinger JL, Ding $X$, Lichti K. Pregnane $X$ receptor and natural products: beyond drug-drug interactions. Expert Opin Drug Metab Toxicol 2006; 2: 847-57.

47. Kim S, Dinchuk JE, Anthony MN, Orcutt $T$, Zoeckler ME, Sauer MB, Mosure KW, Vuppugalla R, Grace JE Jr, Simmermacher J, Dulac HA, Pizzano J, Sinz M. Evaluation of Cynomolgus Monkey Pregnane X Receptor, Primary Hepatocyte, and in Vivo Pharmacokinetic Changes in Predicting Human CYP3A4 induction. Drug Metab Dispos 2010; 38: 16-24.

48. Mannel M. Drug interactions with St John's wort: mechanisms and clinical implications. Drug Saf 2004; 27: 773-97.

49. Choudhuri S, Valerio LG Jr. Usefulness of studies on the molecular mechanism of action of herbals/botanicals: The case of St. John's wort. J Biochem Mol Toxicol 2005; 19: 1-11.

50. Komoroski BJ, Zhang S, Cai H, Hutzler JM, Frye R, Tracy TS, Strom SC, Lehmann T, Ang CY, Cui YY, Venkataramanan R. Induction and inhibition of cytochromes P450 by the St. John's wort constituent hyperforin in human hepatocyte cultures. Drug Metab Dispos 2004; 32: 512-8.

51. Gutmann H, Poller B, Büter KB, Pfrunder A, Schaffner W, Drewe J. Hypericum perforatum: which constituents may induce intestinal MDR1 and CYP3A4 mRNA expression? Planta Med 2006;72: 685-90.

52. Borrelli F, Izzo AA. Herb-Drug Interactions with St John's Wort (Hypericum perforatum): an Update on Clinical Observations. AAPS J 2009; 11: 710-27.

53. Hall $S D$,Wang $Z$, Huang $S M$, Hamman MA, Vasavada N, Adigun AQ, Hilligoss JK, Miller M, Gorski JC. The interaction between St John's wort and an oral contraceptive. Clin Pharmacol Ther 2003; 74: 525-35.

54. Andrén L, Andreasson $\AA$, Eggertsen R. Interaction between a commercially available St. John's wort product (Movina) and atorvastatin in patients with hypercholesterolemia Eur J Clin Pharmacol 2007; 63: 913-6

55. Zhou S, Chan E, Pan SQ, Huang M, Lee EJ. Pharmacokinetic interactions of drugs with St John's wort. Psychopharmacol 2004; 18: 262-76.
56. Qi JW, Nakamura K, Hosokawa S, Okada Y, Horiuchi R, Yamamoto K. Time-dependent induction of midazolam1-hydroxylation enzymes in rats treated with St. John's wort. Biol Pharm Bull 2005; 28: 1467-71.

57. Jiang $X$, Williams KM, Liauw WS, Ammit AJ, Roufogalis BD, Duke CC, Day RO, McLachlan AJ. Effect of St John's wort and ginseng on the pharmacokinetics and pharmacodynamics of warfarin in healthy subjects. Br J Clin Pharmacol 2004; 57: 592-9.

58. Mai I, Bauer S, Perloff ES, Johne A, Uehleke B, Frank B, Budde K, Roots I. Hyperforin content determines the magnitude of the St John's wort-cyclosporine drug interaction. Clin Pharmacol Ther 2004; 76: 330-40.

59. Wang Z, M. Hamman, S. Huang, L. J. Lesko, S. D. Hall. Effect of St John's wort on the pharmacokinetics of fexofenadine. Clin Pharmacol Ther 2002; 71: 414-20.

60. He SM, Yang AK, Li XT, Du YM, Zhou SF. Effects of herbal products on the metabolism and transport of anticancer agents. Expert Opin Drug Metab Toxicol 2010; 6: 1195-213.

61. Komoroski BJ, Parise RA, Egorin MJ, Strom SC, Venkataramanan R. Effect of the St. John's wort constituent hyperforin on docetaxel metabolism by human hepatocyte cultures. Clin Cancer Res 2005; 11: 6972-9.

62. Vlachojannis J, Cameron $M$, Chrubasik S. Drug interactions with St John's wort. Pharmacol Res 2011; 63: 254-56.

63. Imai $H$, Kotegawa $T$, Tsutsumi $K$, Morimoto $T$, Eshima $\mathrm{N}$, Nakano S, Ohashi K.The recovery time-course of CYP3A after induction by St John's wort administration. Br J Clin Pharmacol 2008; 65: 701-7.

64. Hellum $\mathrm{BH}, \mathrm{Hu} Z$, Nilsen OG.Trade herbal products and induction of CYP2C19 and CYP2E1 in cultured human hepatocytes. Basic Clin Pharmacol Toxicol 2009; 105: 5863.

65. Mueller SC, Majcher-Peszynska J, Uehleke B, Klammt S, Mundkowski RG, W Miekisch W, Sievers H, Bauer S, Frank B, Kundt G, Drewelo B. The extent of induction of CYP3A by St. John's wort varies among products and is linked to hyperforin dose. Eur J Clin Pharmacol 2006; 62: 29-36.

66. Mueller SC, Majcher-Peszynska J, Mundkowski RG, Uehleke B, Klammt S, Sievers H Lehnfeld R, Frank B, Thurow K, Kundt G, Drewelow B. No clinically relevant CYP3A induction after St. John's wort with low hyperforin content in healthy volunteers. Eur J Clin Pharmacol 2009; 65: 81-7.

67. Arold G, Donath F, Maurer A, Diefenbach K, Bauer S, Henneicke-von Zepelin HH, Friede M, Roots I.No relevant interaction with alprazolam, caffeine, tolbutamide, and digoxin by treatment with a low-hyperforin St John's wort extract. Planta Med 2005; 71: 331-7.

68. Madabushi R, Frank B, Drewelow B, Derendorf H, Butterweck V. Hyperforin in St. John's wort drug interactions. Eur J Clin Pharmacol 2006; 62: 225-33.

69. Gödtel-Armbrust U, Metzger A, Kroll U, Kelber O, Wojnowski L. Variability in PXR-mediated induction of CYP3A4 by commercial preparations and dry extracts of St. John's wort. Naunyn Schmiedebergs Arch Pharmacol 2007; 375:377-82.

70. Majcher-Peszynska J, Mundkowski RG, Uehleke B, Klammt S, Sievers H, Lehnfeld R, Frank B, Thurow K, Kundt G, Drewelow B. No clinically relevant CYP3A induction after St. John's wort with low hyperforin content in healthy volunteers. Eur J Clin Pharmacol 2009; 65: 81-7. 
71. Komoroski BJ, Zhang S, Cai H, Hutzler JM, Frye R, Tracy TS, Strom SC, Lehmann T, Ang CY, Cui YY, Venkataramanan R. Induction and inhibition of cytochromes P450 by the St. John's wort constituent hyperforin in human hepatocyte cultures. Drug Metab Dispos 2004; 32: 512-8.

72. Rahmioglu N, Heaton J, Clement G, Gill R, Surdulescu G, Zlobecka K, Hodgkiss D, Ma Y, Hider RC, Smith NW, Ahmadi KR.Genetic epidemiology of induced CYP3A4 activity. Pharmacogenet Genomics 2011; 21: 642-51.

73. Schellander R, Donnerer J. Antidepressants: clinically relevant drug interactions to be considered. Pharmacology. 2010; 86: 203-15.

74. Chiang HM, Chao PD, Hsiu SL, Wen KC, Tsai SY, Hou YC Ginger significantly decreased the oral bioavailability of cyclosporine in rats. Am J Chin Med 2006; 34: 84555.

75. Koo KL, Ammit AJ, Tran VH, Duke CC, Roufogalis BD.Gingerols and related analogues inhibit arachidonic acid-induced human platelet serotonin release and aggregation. Thromb Res 2001; 103: 387-97.

76. Verma SK, Bordia A. Ginger, fat and fibrinolysis. Indian J Med Sci 2001; 55: 83-6.

77. Jiang $X$, Williams KM, Liauw WS, Ammit AJ, Roufogalis BD, Duke CC, Day RO, McLachlan AJ Effect of ginkgo and ginger on the pharmacokinetics and pharmacodynamics of warfarin in healthy subjects. Br J Clin Pharmacol 2005; 59: 425-32.

78. Krüth P, Brosi E, Fux R, Mörike K, Gleiter CH. Ginger-associated over anticoagulation by phenprocoumon. Ann Pharmacother 2004; 38: 257-60.

79. Lesho EP, Saullo L, Udvari-Nagy SA 76-year-old woman with erratic anticoagulation. Cleve Clin J Med 2004; 71: 651-6.

80. Young HY, Liao JC, Chang YS, Luo YL, Lu MC, Peng WH.Synergistic effect of ginger and nifedipine on human platelet aggregation: a study in hypertensive patients and normal volunteers. Am J Chin Med 2006; 34: 545-51.

81. Shalansky S, Lynd L, Richardson K, Ingaszewski A, Kerr CRisk of warfarin-related bleeding events and supratherapeutic international normalized ratios associated with complementary and alternative medicine: a longitudinal analysis. Pharmacotherapy 2007; 27: 1237-47.

82. Ali BH, Blunden $G$, Tanira MO, Nemmar A. Some phytochemical, pharmacological and toxicological properties of ginger (Zingiber officinale Roscoe): A review of recent research. Food Cheml Toxicol 2008;46: 409-20.

83. Heeba GH, Abd-Elghany MI. Effect of combined administration of ginger (Zingiber officinale Roscoe) and atorvastatin on the liver of rats.Phytomedicine 2010; 17: 1076-81.

84. Kudolo GB, Dorseya S, Blodgett J. Effect of the ingestion of Ginkgo biloba extract on platelet aggregation and urinary prostanoid excretion in healthy and Type 2 diabetic subjects. Thrombosis Research 2003; 108: 151-60.

85. Jayasekera N, Moghal A, Kashif F. Herbal medicines and postoperative haemorrhage. Anesthesia 2005; 60: 712-13.

86. Gold JL, Laxer DA, Dergal JM, Lanctot KL, Paula A. Rochon PA. Herbal-drug therapy interactions: A focus on dementia. Curr Opin Clin Nutr Metab Care 2001; 4: 29-34.

87. Bebbington A, Kulkarni R, Roberts P.Ginkgo biloba: persistent bleeding after total hip arthroplasty caused by herbal self-medication. J Arthroplasty 2005; 20:125-6.
88. Fessenden JM, Wittenborn W, Clarke L. Gingko biloba: a case report of herbal medicine and bleeding postoperatively from a laparoscopic cholecystectomy. Am Surg 2001; 67: 33-5.

89. Haller CA, Meier KH, Olson KR. Seizures reported in association with use of dietary supplements. Clin Toxicol (Phila) 2005; 43: 23-30.

90. Kim YS, Pyo MK, Park KM, Park PH, Hahn BS, Wu SJ, Yun-Choi HS. Antiplatelet and antithrombotic effects of a combination of ticlopidine and ginkgo biloba ext (EGb 761). Thromb Res 1998; 91: 33-8.

91. Kim BH,Kim KP, Lim KS, Kim JR, Yoon SH, Cho JY, Lee YO, Lee KH, Jang IJ, Shin SG, Yu KS. Influence of Ginkgo biloba extract on the pharmacodynamic effects and pharmacokinetic properties of ticlopidine: an open-label, randomized, two-period, two-treatment, two-sequence, single-dose crossover study in healthy Korean male volunteers. Clin Ther 2010; 32: 380-90.

92. Aruna $D$, Naidu MUPharmacodynamic interaction studies of Ginkgo biloba with cilostazol and clopidogrel in healthy human subjects. Br J Clin Pharmacol 2007; 63: 333-8.

93. Ryu KH, Han HY, Lee $S Y$, Jeon SD, Im GJ, Lee BY, Kim K, Lim KM, Chung JH. Ginkgo biloba extract enhances antiplatelet and antithrombotic effects of cilostazol without prolongation of bleeding time.Thromb Res 2009; 124: 328-3.

94. Jiang $X$, Blair EY, McLachlan AJ. Investigation of the effects of herbal medicines on warfarin response in healthy subjects: a population pharmacokinetic-pharmacodynamic modeling approach. J Clin Pharmacol 2006; 46: 1370-8.

95. Wolf HR. Does Ginkgo biloba special extract EGb 761 provide additional effects on coagulation and bleeding when added to acetylsalicylic acid $500 \mathrm{mg}$ daily? Drugs RD 2006; 7:163-72.

96. Beckert BW, Concannon MJ, Henry SL, Smith DS, Puckett CL.The effect of herbal medicines on platelet function: an in vivo experiment and review of the literature. Plast Reconstr Surg 2007; 120: 2044-50.

97. Bone KM. Potential interaction of Ginkgo biloba leaf with antiplatelet or anticoagulant drugs: what is the evidence? Mol Nutr Food Res 2008; 52: 764-71.

98. Fan L, Tao GY, Wang G, Chen $Y$, Zhang W, He YJ, Li Q, Lei HP, Jiang F, Hu DL, Huang YF, Zhou HH.Effects of Ginkgo biloba extract ingestion on the pharmacokinetics of talinolol in healthy Chinese volunteers. Ann Pharmacother 2009; 43: 944-9.

99. Berecz R, Dorado P, De La Rubia A, Cáceres MC, Degrell I, LLerena A.The role of cytochrome P450 enzymes in the metabolism of risperidone and its clinical relevance for drug interactions. Curr Drug Targets 2004; 5: 573-9.

100. Yeung EYH, Sueyoshi T, Negishi M, Chang TKH. Identification of Ginkgo biloba as a novel activator of pregnane X receptor. Drug Metab dispos 2008; 36: 2270-6.

101. Hellum $\mathrm{BH}$, Nilsen OG. In vitro inhibition of CYP3A4 metabolism and P-glycoprotein-mediated transport by trade herbal products. Basic Clin Pharmacol Toxicol 2008; 102: 466-75.

102. Hellum $B H, H u Z$, Nilsen OG. The induction of CYP1A2, CYP2D6 and CYP3A4 by six trade herbal products in cultured primary human hepatocytes. Basic Clin Pharmacol Toxicol 2007; 100: 23-30. 
103. Sugiyama T, Kubota $Y$, Shinozuka K, Yamada S, Wu J, Umegaki KGinkgo biloba extract modifies hypoglycemic action of tolbutamide via hepatic cytochrome P450 mediated mechanism in aged rats.Life Sci 2004; 75: 1113-22.

104. Uchida $S, Y$ amada $H, L i X D$, Maruyama $S$, Ohmori $Y$, Oki T, Watanabe H, Umegaki K, Ohashi K, Yamada S. Effects of Ginkgo biloba extract on pharmacokinetics and pharmacodynamics of tolbutamide and midazolam in healthy volunteers. J Clin Pharmacol 2006; 46: 1290-8.

105. Zuo XC, Zhang BK, Jia SJ, Liu SK, Zhou LY, Li J, Zhang J, Dai LL, Chen BM, Yang GP, Yuan H. Effects of ginkgo biloba extracts on diazepam metabolism: a pharmacokinetic study in healthy chinese male subjects. Eur J Clin Pharmacol 2010; 66: 503-9.

106. Tang J, Sun J, Zhang Y, Li L, Cui F, He Z. Herb-drug interactions: Effect of Ginkgo biloba extract on the pharmacokinetics of theophylline in rats. Food Chem Toxicol 2007; 45: 2441-5.

107. Taki Y, Yokotani K, Yamada S, Shinozuka K, Kubota Y, Watanabe Y, Umegaki K. Ginkgo biloba extract attenuates warfarin-mediated anticoagulation through induction of hepatic cytochrome P450 enzymes by bilobalide in mice.Phytomedicine 2011 [In press].

108. Yang CY, Chao PD, Hou YC, Tsai SY, Wen KC, Hsiu SL. Marked decrease of cyclosporin bioavailability caused by coadministration of ginkgo and onion in rats. Food Chem Toxicol 2006; 44: 1572-8.

109. Yale SH, Glurich I. Analysis of the inhibitory potential of Ginkgo biloba, Echinacea purpurea, and Serenoa repens on the metabolic activity of cytochrome P450 3A4, 2D6, and 2C9. J Altern Complement Med 2005; 11: 433-9.

110. Lin YY, Chu SJ, Tsai SH. Association Between Priapism and Concurrent Use of Risperidone and Ginkgo biloba. Mayo Clin Proc 2007; 82: 1288-91.

111. Smolinske SC. Dietary supplement-drug interactions. J Am Med Womens Assoc 1999; 54: 191-2,195.

112. Hao $M, B a$, Yin J, Li J, Zhao $Y$, Wang $H$. Deglycosylated Ginsenosides Are More Potent Inducers of CYP1A1, CYP1A2 and CYP3A4 Expression in HepG2 Cells than Glycosylated Ginsenosides. Drug Metab Pharmacokinet 2011; 26: 201-5.

113. Lee $S H$, Ahn YM, Ahn SY, Doo HK, Lee BC. Interaction between warfarin and Panax ginseng in ischemic stroke patients. Altern Complement Med 2008; 14: 715-21.

114. Bilgi N, Bell $K$, Ananthakrishnan AN. Atallah EImatinib and Panax ginseng: a potential interaction resulting in liver toxicity. Ann Pharmacother 2010; 44: 926-8.

115. Gorshki JC, Huang S-M, A Pinto A, Hamman MA, Hilligoss JK, Zaheer NA, Desai M, Miller M, Hall SD. The effect of echinacea (Echinace purpurea root) on cytochrome P450 activity in vivo. Clin Pharmacol Ther 2004; 75: 89-100.

116. Mrozikiewicz PM, Bogacz A, Karasiewicz M, Mikolajczak PL, Ozarowski M, Seremak-Mrozikiewicz A, Czerny B, Bobkiewicz-Kozlowska T, Grzeskowiak E. The effect of standardized Echinacea purpurea extract on rat cytochrome P450 expression level.Phytomedicine 2010; 17: 830-3.
117. Moltó J, Valle M, Miranda C, Cedeño S, Negredo E, Barbanoj MJ, Clotet B. Herb-drug interaction between Echinacea purpurea and darunavir-ritonavir in HIV-infected patients.Antimicrob Agents Chemother 2011; 55: 326-30.

118. Penzak SR, Robertson $S M$, Hunt JD, Chairez $C$, Malati CY, Alfaro RM, Stevenson JM, Kovacs JA. Echinacea purpurea significantly induces cytochrome P450 3A activity but does not alter lopinavir-ritonavir exposure in healthy subjects. Pharmacotherapy 2010; 30: 797-805.

119. Hansen TS, Nilsen OG. Echinacea purpurea and P-glycoprotein drug transport in Caco-2 cells. Phytother Res 2009; 23: 86-91.

120. Heinrich M, Modarai M, Kortenkamp A. Herbal extracts used for upper respiratory tract infections: are there clinically relevant interactions with the cytochrome P450 enzyme system? Planta Med 2008;74: 657-60.

121. Freeman $C$, Spelman K. A critical evaluation of drug interactions with Echinacea spp. Mol Nutr Food Res 2008; 52: 789-98.

122. Toselli F, Matthias A, Gillam EM. Echinacea metabolism and drug interactions: the case for standardization of a complementary medicine. Life Sci 2009; 85: 97-106.

123. Chicca A, Raduner $S$, Pellati $F$, Strompen $T$, Altmann $K H$, Schoop R, Gertsch J. Synergistic immunomopharmacological effects of N-alkylamides in Echinacea purpurea herbal extracts. Int Immunopharmacol 2009; 9: 850-8.

124. Gold JL, Laxer DA, Dergal JM, Lanctot KL, Rochon PA. Herbal-Drug therapy interactions. Curr Opin Clin Nutr Metab Care 2001; 4: 29-34.

125. Carrasco MC, Vallejo JR, Pardo-de-Santayana M, Peral D, Martín MA, Altimiras J. Interactions of Valeriana officinalis L. and Passiflora incarnata L. in a patient treated with lorazepam. Phytother Res 2009; 23: 1795-6.

126. Chaplin RL Jr, Jedynak J, Johnson D, Heiter D, Shovelton $\mathrm{L}$, Garrett N. The effects of valerian on the time course of emergence from general anesthesia in Sprague-Dawley rats (Rattus norvegicus). AANA J 2007; 75: 431-5.

127. Dalla Corte $C L$, Fachinetto $R$, Colle $D$, Pereira RP, Avila DS, Villarinho JG, Wagner C, Pereira ME, Nogueira CW, Soares FA, Rocha JB. Potentially adverse interactions between haloperidol and valerian. Food Chem Toxicol 2008; 46: 2369-75.

128. Donovan JL, DeVane CL, Chavin KD, Wang JS, Gibson BB, Gefroh HA, Markowitz JS. Multiple night-time doses of valerian (Valeriana officinalis) had minimal effects on CYP3A4 activity and no effect on CYP2D6 activity in healthy volunteers. Drug Metab Dispos 2004; 32: 1333-6.

129. Hamann GL, Campbell JD, George CM. Warfarin-Cranberry juice interaction. Ann Pharmacother 2011; 45:e17.

130. Yap KY, See CS, Chan A. Clinically-relevant chemotherapy interactions with complementary and alternative medicines in patients with cancer. Recent Pat Food Nutr Agric 2010; 2: 12-55. 